\title{
KEDUDUKAN ANAK HASIL ZINA DITINJAU DARI HUKUM ISLAM DAN UNDANG-UNDANG NOMOR 1 TAHUN 1974 TENTANG PERKAWINAN
}

\author{
Lukman Hakim \\ Fakultas Keguruan dan Ilmu Pendidikan \\ Universitas Muhammadiyah Sumatera Utara \\ Email: lukman4dara@gmail.com
}

\begin{abstract}
The child of adultery has been controversial in law when it comes to talk about the rights that it should have. The controversy related to the line of descent, disinherited and other rights associated with the law. Islamic law considers the child of adultery naturally has the line of descent with his mother as well as disinherited. On the other side of the existing regulations in Indonesia, particularly Article 867 to Article 869 of the Civil Code, that child of adultery cannot be an heir of her mother and her biological father, they are only entitled to subsistence necessary.
\end{abstract}

Kata Kunci: Kedudukan Anak, Anak Hasil Zina, Hukum Islam, Perkawinan

\section{A. Latar Belakang}

Perkawinan adalah suatu ikatan lahir dan batin antara seorang pria dan wanita sebagai suami atau istri dengan tujuan untuk membentuk suatu keluarga (rumah tangga) yang bahagia dan kekal berdasarkan Ketuhanan Yang Maha Esa, yang harus dilaksanakan sesuai agamanya masing-masing, dan harus juga harus dicatat menurut peraturan perundang-undangan yang berlaku (Munir Fuadi 2014: $10)$.

Pasal 2 Undang-undang Nomor 1 Tahun 1974 tentang Perkawinan (UU No. 1 Tahun 1974), menunjukkan bahwa perkawinan di Indonesia tidak sematamata berkenaan dengan hubungan keperdataan kodrati pribadi. Dalam pasal itu juga turut campurnya agama atau kepercayaan individu bertujuan melaksanakan ibadah agamanya masing-masing. Bagi yang tidak beragama, tetapi menganut suatu kepercayaan hendaknya tetap berpendirian seperti itu, supaya sikap disiplin kepada dirinya selalu ada. Dalam melaksanakan kodrati pribadi melaksanakan kodrati pribadi melanjutkan keturunan dengan membentuk keluarga, peristiwa itu 
akan dicatat, dan melalui pencatatan maka masing-masing akan diberikan akta perkawinan.

UU No. 1 Tahun 1974 bertujuan mengatur pergaulan hidup yang sempurna bahagia, dan kekal di dalam rumah tangga guna terciptanya rasa kasih sayang dan saling mencintai, tetapi dalam kenyataannya tujuan tersebut tidak dapat selalu dicapai, karena tidak adanya kesepahaman di antara mereka dalam menjalankan perkawinan. Perkembangan zaman yang terus berganti, berkembang dan semakin maju, serta semakin besar pengaruh budaya barat dengan paham kebebasan, membawa akibat terhadap perkembangan pola pergaulan anak muda zaman sekarang, dimana norma hukum dan agama banyak yang terabaikan sehingga sering membawa kepada hal-hal yang negatif, salah satunya adalah kehamilan yang terjadi di luar perkawinan.

Hamil sebelum menikah telah menjadi problematika dan kegelisahan dalam masyarakat terutama pada orang tua yang bersangkutan, karena perbuatan tersebut merupakan aib bagi keluarga. Salah satu hal yang penting tentang keberadaan umat manusia di dunia adalah asal-usul anak yang dilahirkan, karena asal-usul anak merupakan dasar untuk menunjukkan adanya hubungan nasab atau hubungan hukum dengan ayahnya.

Lahirnya seorang anak didahului oleh adanya hubungan antara seorang laki-laki dengan perempuan, hubungan tersebut dapat terjadi di dalam suatu ikatan perkawinan yang sah, tetapi hubungan itu dapat pula terjadi berdasarkan hubungan biologis semata tanpa ikatan perkawinan yang sah atau dapat disebut dengan zina. Hukum membedakan antara keturunan yang sah dan keturunan yang tidak sah didasarkan atas adanya perkawinan yang sah atau tidak.

Sebuah perkawinan yang sah terdapat anak yang tumbuh dan dilahirkan sepanjang perkawinan disebut sebagai anak-anak sah dan ada anak-anak yang tumbuh dan dilahirkan di luar perkawinan disebut anak-anak yang tidak sah. Anak yang tumbuh atau dilahirkan sepanjang perkawinan orang tuanya disebut anak sah, di mana ia secara otomatis akan mempunyai nasab dengan kedua orang tuanya. Hubungan nasab tersebut nantinya akan melahirkan hubungan hukum antara orang tua dan anak. Keturunan (anak-anak) sah tersebut dapat dibuktikan 
dengan akta kelahiran mereka yang telah dibukukan dalam Kantor Catatan Sipil, yang di dalamnya tersebut nama kedua orang tuanya.

Anak yang dilahirkan dari orang tuanya yang tidak terikat dalam suatu perkawinan disebut anak yang tidak sah atau anak-anak luar nikah. Secara biologis anak tersebut memang mempunyai hubungan darah dengan kedua orang tuanya, tetapi yang menjadi masalah adalah apakah anak tersebut juga mempunyai hubungan hukum dengan kedua orang tuanya.

Ketentuan yang membedakan anak sah dan anak luar kawin terkadang dirasakan kurang adil, karena anak-anak yang lahir ke dunia sama sekali tidak mempunyai dosa. Seringkali anak yang dilahirkan di luar perkawinan atau zina mendapat pandangan negatif dari masyarakat yang terbawa dalam kehidupan sehari-hari anak tersebut, baik dalam lingkungan masyarakat ataupun keluarganya sendiri.

Keberadaan anak luar nikah atau zina, telah menyebabkan banyak keluarga yang merasa malu dan merasa terbebani dengan kehadiran anak luar nikah atau zina, sehingga sering kali menyebabkan anak yang lahir di luar nikah atau zina diperlakukan secara tidak adil oleh orang tua biologisnya. Berdasarkan uraian ini, maka dapat dikatakan bahwa keberadaan anak luar nikah mempunyai aspek hukum terutama hubungannya menurut Hukum Islam dan UU No. 1 Tahun 1974. Oleh sebab itu perlu dilakukan kajian yang bertujuan untuk mengetahui kedudukan anak hasil zina ditinjau dari Hukum Islam dan UU No. 1 Tahun 1974.

\section{B. Metode Penelitian}

Jenis penelitian hukum dapat dibedakan menjadi penelitian hukum normatif dan penelitian hukum empiris/sosiologis. Penelitian hukum normatif merupakan penelitian yang datanya bersumber pada data sekunder dan berhubung data penelitian ini adalah data sekunder, maka termasuk dalam jenis penelitian hukum normatif. Sifat penelitian ini adalah deskriptif, yang bertujuan untuk memberikan gambaran tentang gejala-gejala sosial yang terkait dengan masalah kedudukan anak hasil zina. Sumber data penelitian berupa bahan hukum primer, bahan hukum sekunder dan bahan hukum tersier. Metode pengumpulan data 
dilakukan menggunakan teknik studi dokumen, yang dianalisis dengan menggunakan teknik analisis kualitatif.

\section{Hasil Penelitian dan Analisis}

\section{Ruang lingkup dan tinjauan umum tentang zina}

Ruang lingkup ini dikemukakan agar diperoleh batasan yang jelas terhadap defenisi zina. Zina menurut Ensiklopedi Hukum Islam adalah hubungan seksual antara seorang laki-laki dan perempuan yang tidak atau belum diikat dalam perkawinan tanpa disertai unsur keraguan dalam hubungan seksual tersebut (Neng Djubaedah 2010: 119). Neng Djubaedah (2010: 120) menjelaskan bahwa zina menurut syara' dan bahasa adalah seorang laki-laki yang menyetubuhi perempuan melalui qubul (vagina atau kemaluan), yang bukan dengan istrinya, tanpa melalui perkawinan atau syubhatun nikah (perkawinan yang syubhat).

Perzinaan merupakan masalah yang tidak akan pernah habis diperbincangkan sepanjang hidup manusia dan sepanjang masa, karena pada prinsipnya setiap manusia menghendaki adanya sikap perilaku yang baik antar-sesama. Masalah perzinaan tidak hanya menyangkut hubungan antar-manusia sebagai hak insani atau hak adami, tetapi masalah perzinaan dan hukumannya memang begitu penting dalam rangka pemeliharaan hubungan antar manusia dan karena betapa dahsyatnya akibat perzinaan terhadap hidup dan kehidupan manusia itu sendiri.

Isi kandungan Al-Qur'an yang memuatkan ketentuan-ketentuan tentang larangan perzinaan dan hukumannya serta pembuktiannya, dapat diketahui antara lain dalam Surat an-Nisa Ayat 15 dan 16, Surat An-Nur Ayat 2, 4, 6 sampai Ayat 9 dan Ayat 13, dalam hadis-hadis Rasulullah SAW tentang Ma'iz bin Malik dan Gamidiyah dan dalam kitab-kitab fikih sebagai hasil pemikiran dan ijtihad para fuqaha.

Allah sebagai al-khaliq, Maha Pencipta alam semesta antara lain manusia, adalah maha mengetahui mengenai tabiat atau watak ciptaan-Nya. Demikian pula dalam hal hasrat seksual antara laki-laki dan perempuan, oleh karena itu, Allah telah menentukan ketentuan-ketentuan hukum yang berkaitan dengan perzinaan, 
sebagai tanda cinta Allah kepada hamba-Nya, agar setiap manusia tetap suci dan memelihara diri dari perbuatan keji, antara lain zina (Neng Djubaedah 2010: 7).

Banyak diantara manusia belum sadar atau belum mengetahui, bahkan tidak mau tahu, bahwa setiap hukum yang qath'i maupun zanni dalam Al-Qur'an maupun hadis Rasulullah adalah perwujudan sifat Allah yang Maha rahman dan Maha rahim kepada makhluk-Nya.

Ketentuan hukum tersebut sering mendapat penilaian sebagai hukum yang tidak manusiawi, melanggar hak asasi manusia, atau disebut sebagai hukuman yang hanya dapat diterapkan pada masa turunnya ayat hukum tersebut, Karena saat ini hukum Allah, menurut kalangan yang menolak hukum Allah tentang perzinaan, sudah tidak sesuai dengan perkembagan zaman. Bahkan hukum Allah sering disebutkan atau mendapat predikat sebagai hukum yang kejam dan sadis, juga termasuk hukuman terhadap pelaku zina berupa rajam maupun cambuk (Neng Djubaedah 2010: 7)

Dilihat dari bentuk hukuman zina semata, tanpa melihat dan mengkaji aspek lain yang berkaitan dengan perzinaan berdasarkan syariah Islam maupun nilai-nilai Islam, tentu melihat perzinaan akan menjadi lain dan berbeda. Misalnya, dampak dari perbuatan zina terhadap pihak lain maupun susunan kemasyarakatan tanpa menghubungkannya dengan hukum kekeluargaan ( hukum perkawinan dan hukum kewarisan) sesuai Islam, tentu akan berbeda dengan pandangan sekuler.

Dengan kata lain, jika melihat perbuatan zina itu hanya semata-mata sebagaimana cara pandang dan cara pikir orang-orang Barat (Belanda), maka akan berbeda dengan cara pandang orang Islam yang mendasarkan pemikirannya dan pandangannya kepada hukum Islam. Pelaku hubungan seksual di luar nikah dapat diindetifikasikan sebagai tindak pidana zina, apabila hubungan seksual di luar perkawinan itu dilakukan oleh kedua pelaku zina atau salah satunya adalah masih terikat dalam perkawinan yang sah dengan orang lain.

Kehamilan perempuan di luar nikah itu bukan peristiwa baru bahkan sepanjang kehidupan manusia peristiwa tersebut tidak mungkin lenyap, meskipun demikian setiap manusia mempunyai kewajiban untuk berusaha menyelamatkan 
hidup dan kehidupan diri, keluarganya, serta anggota masyarakat lain dari perbuatan yang merusak diri manusia sendiri.

Perzinaan merupakan perbuatan yang dapat merusak manusia, baik terhadap diri pribadi, keluarga maupun masyarakat, didunia maupun akhirat. Dari rumusan Pasal 284 KUHP yang melarang setiap orang di Indonesia melakukan perbuatan mukah atau zina tetapi hanya terhadap orang-orang yang salah satu atau kedua pelakunya masih terikat perkawinan yang sah dengan orang lain (Neng Djubaedah 2010: 10). Pasal tersebut juga menentukan bahwa delik mukah (zina) itu merupakan delik aduan mutlak, bukan delik umum dan diadukan oleh pihak yang tercemar, dalam melakukan pengaduan tersebut, pihak yang tercemar harus melakukannya dengan disertai permintaan perceraian atau pisah meja dan tempat tidur.

Para penegak hukum maupun para ahli hukum banyak yang menyetujui delik perzinaan tetap diatur sebagai salah satu delik baik dalam hukum pidana sekarang maupun untuk hukum pidana masa yang akan datang, walaupun pengertian perzinaan menurut aturan hukum pidana sekarang tidak seluas perzinaan menurut pandangan masyarakat. Menurut Kitab Undang-undang Hukum Pidana (KHUP) yang dimaksud dengan zina adalah persetubuhan yang dilakukan oleh laki laki atau perempuan yang sudah kawin dengan perempuan atau laki laki yang bukan istri atau suaminya. Agar dapat termasuk dalam pasal ini maka persetubuhan itu harus didasarkan atas suka sama suka, tidak boleh adanya paksaan oleh salah satu pihak. Bukanlah dikatakan zina apabila perzinaan itu dilakukan dengan paksaan (Pasal 285), persetubuhan dengan perempuan dalam keadaan pingsan atau tidak berdaya (Pasal 286 ) dan persetubuhan dengan perempuan yang belum cukup umur lima belas tahun (Pasal 287).

Sue Titus Reid sebagaimana dikutip Neng Djubaedah (2010: 183), berpendapat bahwa, fornication adalah hubungan seksual yang tidak sah diantara dua orang yang masing-masing tidak terikat perkawinan. Dalam beberapa pendapat, menurut Reid, fornication juga diterapkan terhadap seorang yang tidak terikat perkawinan yang melakukan hubungan seksual dengan seorang yang terikat perkawinan dengan orang lain 
Larangan fornication tidak diatur secara tegas dalam KUHP, kecuali fornication dengan anak yang belum 15 (lima belas) tahun atau anak yang belum waktunya untuk dinikahi, diancam hukum penjara paling lama 9 tahun sebagaimana ditentukan dalam Pasal 287 ayat (1) KUHP. Jenis deliknya pun merupakan delik aduan, bukan delik umum, sebagaimana dirumuskan dalam Pasal 287 Ayat (2) KUHP. Pasal 287 Ayat (1) menentukan bahwa: barang siapa bersetubuh dengan seorang wanita di luar perkawinan, padahal diketahuinya atau sepatutnya harus diduganya bahwa umurnya belum lima belas tahun, atau umurnya tidak jelas, bahwa belum waktunya untuk dikawin, diancam dengan pidana paling lama sembilan tahun. (Andi Hamzah 2007: 115)

R. Soesilo merumuskan unsur-unsur delik yang harus dipenuhi menurut Pasal 287 KUHP:

a. Perempuan itu harus bukan istrinya, dan jika istrinya sendiri, mungkin dapat dikenakan Pasal 288, tetapi persetubuhan itu harus berakibat luka pada tubuh perempuan tersebut.

b. Persetubuhan itu harus betul-betul dilakukan, dan jika belum betul-betul dilakukan, maka perbuatan itu dapat dikenakan Pasal 290 ayat (2), yaitu hanya termasuk perbuatan cabul.

c. Pelaku pelanggaran harus mengetahui atau patut dapat menyangka, bahwa perempuan belum berumur 15 (lima belas) tahun, jika umur itu belum nyata, bahwa perempuan itu belum masanya untuk dikawini.

d. Peristiwa tersebut merupakan delik aduan, kecuali jika usia perempuan tersebut belum mencapai 12 (dua belas) tahun atau peristiwa tersebut berakibat luka berat atau mati.

Ditinjau dari Hukum Islam, larangan fornication atau hubungan seksual antara orang yang masing-masing tidak terikat dalam perkawinan dan dilakukan atas dasar suka sama suka, termasuk larangan incest, adalah tetap merupakan perbuatan zina. Hal itu, disebabkan pengertian zina adalah meliputi semua hubungan seksual yang dilakukan di luar perkawinan dengan orang lain ataupun tidak terikat perkawinan dengan siapaun juga. 
Perzinaan oleh orang yang terikat perkawinan (adultery) adalah perbuatan seksual yang diyakini sebagai perbuatan inmoral yang merupakan yurisdiksi membatasi adultery sebagai hubungan seksual yang dilakukan antara dua orang yang apabila salah satunya terikat perkawinan dengan orang lain. Beberapa yurisdiksi lainnya menentukan bahwa adultery hanya pasangan yang keduanya sama-sama terikat perkawinan dengan orang lain.

Ketentuan hukum adultery hanya bagi seorang perempuan yang terikat perkawinan, karena biasanya laki-laki menikah yang melakukan hubungan seksual dengan orang lain yang bukan istrinya adalah bukan merupakan kejahatan. Pemikiran para pakar hukum dari Barat tersebut memengaruhi, bahkan mungkin sebagai sumber dirumuskannya ketentuan hukum pidana yang berlaku di Indonesia, yang menentukan bahwa hubungan seksual di luar nikah yag dilakukan oleh yang terikat dalam perkawinan adalah dilarang (Andi Hamzah 2007: 200201).

Apabila kita cermati lagi, ketentuan perzinaan dalam KUHP yang berlaku saat ini bertujuan untuk mengkriminalisasi pelaku perselingkuhan di mana salah seorang atau kedua pelaku persetubuhan itu merupakan orang yang sudah terikat dengan ikatan perkawinan sebelumnya. Selain itu Pasal 284 KUHP adalah merupakan delik aduan absolut yang tidak memungkinkan perbuatan itu dipidana Jika tidak ada yang mengadukan dari pihak yang dirugikan (suami atau istri yang dikhianati pasangannya) dan, selama perkara itu belum diperiksa dimukan pengadilan. maka senantiasa pengaduan itu dapat ditarik kembali. Dapat disimpulkan perancang pasal tersebut yang pada saat itu merupakan Pemerintah Kolonial Belanda mengkriminalisasikan tindak pidana perzinaan ini dengan alasan untuk menjaga kesucian ikatan perkawinan bagi orang yang telah kawin. Selama kedua belah pihak yang melakukan persetubuhan belum terikat dengan ikatan perkawinan maka delik perzinaan tersebut belum dapat dikenakan.

Rumusan tindak pidana zina dalam Pasal 284 KUHP adalah perzinaan yang dilakukan oleh dua orang yang salah satu atau keduanya terikat perkawinan dan diadukan oleh isteri atau suami pelaku zina dan dilakukan atas dasar suka sama suka. Hukumannya adalah maksimal sembilan bulan penjara. Untuk tindak 
pidana ini KUHP menempatkannya sebagai tindak pidana aduan. Pengaturan ini membuka ruang dan kesempatan yang sangat luas bagi merebaknya tindak pidana perzinaan dalam berbagai bentuk dan variasinya. Keberadaan Pasal tersebut tentunya sudah sangat tidak relevan dan tidak dapat dikatakan bahwa Pasal tersebut ideal sebagai sebuah produk hukum yang menjamin tegaknya keamanan dan ketentraman dalam kehidupan masyarakat sebagaimana tujuan hukum yang di cita-citakan.

Substansi pasal tentang perzinahan dalam KUHP tidak mampu mencerminkan dan mengakomodir nilai-nilai hukum yang hidup dalam masyarakat, baik hukum adat maupun hukum agama. Hal ini tentunya harus menjadi bahan perenungan dan kajian yang mendalam bagi para akademisi yang memiliki konsensen terhadap eksistensi Hukum Islam, para pakar hukum dan pemerhati Hukum Islam serta masyarakat pada umumnya. Sumber hukum Islam yang ada memiliki kepastian hukum yang mampu menjamin ketentraman dan kebahagian dalam kehidupan umat manusia. Oleh karena itu KUHP sebagai produk hukum hendaknya menjadi sebuah kebutuhan nasional yang sangat mendesak untuk dikaji ulang dalam rangka untuk pembaharuan hukum yang lebih menjamin keadilan dan ketentraman hidup masyarakat.

\section{Kedudukan anak hasil zina}

Keberadaan anak dalam keluarga merupakan sesuatu yang sangat berarti anak memiliki arti yang berbeda-beda bagi setiap orang. Anak merupakan penyambung keturunan, sebagai investasi masa depan, dan anak merupakan harapan untuk menjadi sandaran dikala usia lanjut. Anak dianggap sebagai modal untuk meningkatkan peringkat hidup sehingga dapat mengontrol status sosial orang tua. Begitu pentingnya eksistensi anak dalam kehidupan manusia, maka Allah mensyari'atkan adanya perkawinan. Pensyari'atan perkawinan memiliki tujuan antara lain untuk berketurunan (memiliki anak) yang baik, memelihara nasab, menghindarkan diri dari penyakit dan menciptakan keluarga yang sakinah mempunyai akibat hukum keperdataan secara luas.

Undang-undang Nomor 1 Tahun 1974 tentang Perkawinan tidak menjelaskan secara rinci tentang pengakuan anak di luar kawin atau zina, hanya dijelaskan 
bahwa anak luar kawin adalah anak yang dilahirkan dari perkawinan yang tidak sah dan ia hanya mempunyai hubungan perdata dengan ibu yang melahirkannya atau keluarga ibunya. Kedudukan anak luar kawin atau zina akan diatur secara tersendiri dalam peraturan pemerintah.

Banyak sekali hal-hal yang dapat mengakibatkan nasab seorang anak tidak jelas, permasalahan yang muncul di tengah-tengah masyarakat adalah seks bebas yang banyak terjadi pada pergaulan anak muda pada zaman globalisasi ini, bermula dari adat pacaran yang sudah menjerumus pada pergaulan bebas sampai berakibat hamil di luar nikah.

Perkawinan siri yang banyak dilakukan, dengan alasan pelaku menghindari dosa berzina. Perkawinan siri secara agama memang sah, karena sudah memenuhi rukun nikah, tetapi dalam hukum Perkawinan Indonesia yang tidak dicatatkan di KUA tidak diakui keberadaanya. Hal ini sebenarnya juga menimbulkan efek terhadap perkembangan anak yang dilahirkannya kelak.

Syariat pernikahan merupakan salah satu hukum yang ditetapkan oleh Allah SWT. Demi kemaslahatan seluruh umat manusia, guna menyalurkan kodrat manusia dalam menyalurkan nafsu birahi secara benar dan teratur memberikan keturunan yang sah, selain mewujudkan suasana rumah tangga yang sakinah, mawaddah dan rahmah.

Memelihara nasab atau nasal adalah salah satu tujuan utama Hukum Islam, tujuan umum Hukum Islam adalah mewujudkan kemaslahatan (kebaikan dan kesejahteraan) manusia. Nasab adalah salah satu dari hak anak yang kelima, yakni susuan (nasab), pemeliharaan, perwalian/perlindungan, dan nafkah, sebab ditetapkannya nasab seorang anak pada Ibunya, adalah adanya kelahiran, baik kelahiran itu akibat persetubuhan yang sesuai dengan syara' maupun karena persetubuhan yang menyalahi syara'.

Penetapan atau kedudukan anak dalam perspektif Hukum Islam memiliki arti yang sangat penting, karena dengan penetapan itulah dapat diketahui hubungan mahram (nasab) antara anak dengan ayahnya. Kendatipun pada hakikatnya setiap anak yang lahir berasal dari sperma seorang laki-laki dan 
sejatinya harus menjadi ayahnya, tetapi Hukum Islam memberikan ketentuan lain (Amiur Nuriddin dan Azhari Akmal Tarigan 2004: 276).

Seorang anak dapat dikatakan sah memiliki hubungan nasab dengan ayahnya jika terlahir dari perkawinan yang sah. Sebaliknya anak yang lahir di luar perkawinan yang sah, tidak dapat disebut dengan anak yang sah, biasa disebut dengan anak zina atau anak di luar perkawinan yang sah dan ia hanya memiliki hubungan nasab dengan ibunya.

Menurut Hukum Perdata yang berlaku di Indonesia, penetapan atau kedudukan anak dapat dilakukan dengan pengakuan secara sukarela dan pengakuan yang dipaksakan. Pengakuan anak secara sukarela adalah pernyataan sebagaimana yang ditentukan dalam hukum perdata bahwa seorang ayah dan ibu mengakui seorang anak yang lahir dari seorang ibu itu betul anak dari hasil hubungan biologis mereka dan hubungan itu tidak dalam ikatan perkawinan yang sah (Abdul Manan 2006: 99).

Anak yang lahir dari perbuatan zina dan sumbang tidak diperkenankan untuk diakui oleh orang yang berbuat zina, kecuali ada dispensasi dari Presiden, berdasarkan dari ketentuan ini maka anak zina dan sumbang tidak bisa dipaksakan pengakuannya kepada laki-laki yang membuahinya. Hal ini didasarkan kepada asas hukum perdata yang menentukan bahwa dalam hukum perkawinan harus dihormati ketentuan-ketentuan dan norma-norma yang berlaku dalam masyarakat.

Pasal 281 Kitab Undang-Undang Hukum Perdata disebutkan ada tiga cara untuk mengakui anak luar kawin, yaitu (1) di dalam akta kelahiran anak yang bersangkutan, (2) di dalam akta perkawinan yang ada, (3) di dalam akta autentik. Dalam praktik hukum perdata, cara yang sering dimuat adalah pengakuan oleh seorang ayah yang namanya disebutkan dalam akta kelahiran anak yang bersangkutan.

Cara yang kedua dilaksanakan dengan cara melaksanakan perkawinan sah antara wanita yang hamil dengan pria yang membuahinya sekaligus mengakui anak luar kawin atau zina, yang diakui disini adalah anak luar kawin atau zina yang sudah dilahirkan dan pada waktu melaporkan kelahiran belum diberikan pengakuan oleh ayahnya. 
Pengakuan cara ketiga adalah pengakuan yang dituangkan dalam akta autentik berupa akta notaris, pengakuan ini ditindak lanjuti dengan melaporkan kepada Kantor Catatan Sipil dimana kelahiran anak itu dahulu telah didaftarkan dan minta agar pengakuan itu dicatat dalam minut akta kelahiran yang bersangkutan.

Literatur ilmu fikih tidak terdapat secara khusus membahas tentang pengakuan dan penetapan asal usul anak secara lengkap sebagaimana yang tersebut dalam hukum perdata barat, tetapi secara substansial dapat ditemukan dalam bab yang membahas tentang hukum-hukum kekeluargaan, khususnya tentang da'waan nasab. Hampir semua kitab fikih membahas tentang perlunya perlindungan terhadap anak terlantar, anak luar kawin.

Mazhab Syafi'i menyebutkan bahwa anak dari hasil perzinaan tidak mempunyai akibat hukum terhadap pihak ayah biologisnya, bahkan anak dari hasil perzinaan boleh dinikahi dari ayah biologisnya, tetapi hukumnya makruh, dikarenakan untuk menghindari khilafiyah di antara ulama.

Dalam mazhab Syafi'i dijelaskan bahwa anak yang lahir setelah enam bulan dari perkawinan ibu-bapaknya, anak itu dinasabkan kepada bapaknya, dan jika anak itu dilahirkan sebelum enam bulan maka hanya dinasabkan kepada ibunya, karena diduga ibunya telah melakukan hubungan seks dengan orang lain, sedangkan batas waktu hamil, paling kurang enam bulan.

Islam melarang keras perbuatan zina, karena tidak sesuai dengan sifat kemanusiaan dan perbuatan tersebut dapat menghancurkan moral dan mengotori $n a s a b$, Islam selalu melarang umatnya mendekati perbuatan keji dan hina karena akan menimbulkan akibat yang buruk. Tampaknya fikih Islam menganut pemahaman yang cukup tegas berkenaan dengan anak yang sah. Kendatipun tidak ditemukan defenisi yang jelas dan tegas berkenaan dengan anak yang sah, tetapi berangkat dari defenisi ayat-ayat al-Qur'an dan Hadist, dapat diberikan batasan, anak yang sah adalah anak yang lahir oleh sebab dan di dalam perkawinan yang sah. Selain itu,disebut sebagai anak zina (walad al-zina) yang hanya memiliki hubungan nasab dengan ibunya (Amiur Nuriddin dan Azhari Akmal Tarigan 2004: 277). 
Anak zina adalah anak yang dilahirkan ibunya dari hubungan yang tidak sah, dan anak li'an adalah anak yang secara hukum tidak dinasabkan kepada bapaknya,setelah suami istri saling meli'an dengan sifat tuduhan yang jelas (Amiur Nuriddin dan Azhari Akmal Tarigan 2004: 278).

Defenisi di atas membicarakan dua jenis status anak. Anak zina yang lahir dari hubungan yang tidak sah (zina) dan anak li'an. Apabila terjadi perkawinan antara suami dan istri secara sah,kemudian istri mengandung dan melahirkan anaknya, maka suami dapat mengingkari kesahan anak itu apabila:

a. Istri melahirkan anak sebelum masa kehamilan.

b. Melahirkan anak setelah lewat batas maksimal masa kehamilan dari masa perceraian.

Seorang anak yang lahir dari hasil zina sebelum 6 bulan masa kehamilan menurut Imam Malik dan Syafi'i, anak yang lahir setelah enam bulan dari perkawinan ibu bapaknya, anak itu dapat dinasabkan kepada bapaknya, tetapi jika anak itu dilahirkan sebelum enam bulan dari perkawinan ibu bapaknya, maka dinasabkan kepada ibunya saja, karena diduga ibunya telah melakukan hubungan badan dengan orang lain, artinya tidak ada hubungan kewarisan antara anak zina dengan ayahnya.

Mazhab Syafi'i berpendapat bahwa wanita hamil di luar nikah tidak ada ‘ddahnya. Menurut mereka wanita yang berzina tidak ditentukan ketentuanketentuan hukum sebagaimana yang ditetapkan oleh nikah syar' $i$, karena iddah itu disyari'atkan untuk memelihara keturunan dan menghargai sperma. Dalam hal ini sperma zina tidak dihargai, dengan alasan tidak ditetapkannya keturunan anak zina kepada ayah biologis, tetapi kepada ibunya.

Berdasarkan penjelasan tersebut di atas bahwa anak zina atau anak luar perkawinan menurut Fiqih Islam, hanya dinasabkan kepada ibunya saja, sedangkan masalah anak sah dan tidak sah diatur di dalam Undang-undang No. 1 Tahun 1974, pada Pasal 42 sampai dengan Pasal 44, yang menentukan sebagai berikut:

a. Anak yang sah adalah anak yang dilahirkan dalam atau sebagai akibat perkawinan yang sah. 
b. Anak yang dilahirkan di luar perkawinan hanya mempunyai hubungan perdata dengan ibunya dan keluarga ibunya.

c. Seorang suami dapat menyangkal sahnya anak yang dilahirkan oleh istrinya bilamana ia dapat membuktikan bahwa istrinya telah berzina dan anak itu akibat daripada perzinaan tersebut.

d. Pengadilan memberikan keputusan tentang sah/tidaknya anak atas permintaan pihak yang bersangkutan.

Berkenaan dengan pembuktian asal-usul anak, Pasal 55 Undang-undang No. 1 Tahun 1974 menegaskan:

a. Asal-usul seorang anak hanya dapat dibuktikan dengan akte kelahiran yang autentik,yang dikeluarkan oleh pejabat yang berwenang.

b. Bila akte kelahiran tersebut tidak ada, Pengadilan dapat mengeluarkan penetapan asal-usul seorang anak setelah diadakan pemeriksaan yang diteliti berdasarkan bukti-bukti yang memenuhi syarat.

c. Atas dasar ketentuan Pengadilan tersebut ni, maka instansi Pencatat Kelahiran yang ada dalam daerah hukum Pengadilan yang mengeluarkan akte kelahiran bagi anak yang bersangkutan.

Ketentuan pasal-pasal sebagaimana disebutkan di atas, ada beberapa hal yang diatur. Pertama, anak sah adalah yang lahir dalam dan akibat perkawinan yang sah. Paling tidak ada dua bentuk kemungkinan anak sah lahir akibat perkawinan yang sah dan anak yang lahir dalam perkawinan yang sah. Kedua, lawan anak sah adalah anak luar perkawinan yang hanya memiliki hubungan perdata dengan ibunya saja. Ketiga, suami berhak melakukan pengingkaran atau penyangkalan terhadap sahnya seorang anak. Keempat, bukti asal-usul anak dapat dilakukan dengan akta kelahiran (Amiur Nuriddin dan Azhari Akmal Tarigan 2004: 281-282).

Kemudian Pasal 99 Kompilasi Hukum Islam memuat ketentuan defenitif bahwa anak yang sah adalah anak yang dilahirkan dalam suatu akibat perkawinan yang sah. Hasil pembuahan suami istri yang sah di luar rahim dan dilahirkan oleh istri tersebut. Anak yang lahir di luar perkawinan, menurut pasal 100 Kompilasi 
Hukum Islam, hanya mempunyai hubungan nasab dengan ibunya dan keluarga ibunya (Amiur Nuriddin dan Azhari Akmal Tarigan 2004: 283).

Berdasarkan uraian di atas dapat disimpulkan bahwasanya anak yang sah adalah anak yang dilahirkan dalam atau sebagai akibat perkawinan yang sah. Sedangkan anak yang tidak sah adalah anak yang dilahirkan dalam ikatan perkawinan yang tidak berada dalam perkawinan yang sah.

Perkawinan tidak menentukan hubungan hukum antara anak hasil zina dengan ayah biologisnya, dengan kata li'an hubungan perkawinan tidak mempengaruhi atau tidak menentukan hubungan keperdataan (nasab) antara anak hasil zina dengan ayah biologisnya. Dalam Pasal 283 KUH Perdata ditentukan bahwa anak yang dihasilkan dari hubungan zina menurut hukum Barat, yaitu anak yang dilahirkan sebagai akibat hubungan seksual yang dilakukan perempuan yang terikat dalam perkawinan dengan laki-laki yang bukan suaminya, disebut anak zina atau anak sumbang, ia tidak boleh diakui (R.Subekti dan R.Tjitrosudibio 1999: 70). Akibat hukumnya tampak dalam hukum kewarisan Barat dalam Pasal 867 sampai dengan Pasal 869 KUH Perdata, bahwa anak hasil zina tersebut tidak dapat menjadi ahli waris dari ibunya maupun ayah biologisnya,mereka hanya berhak atas nafkah hidup seperlunya (R.Subekti dan R.Tjitrosudibio 1999: 230).

Apabila ketentuan hukum perkawinan dan hukum kewarisan KUH Perdata Barat yang berlaku di Indonesia saat ini dibandingkan dengan Hukum Islam berdasarkan al-Qur'an dan as-Sunnah Rasulullah SAW, maka hukum perkawinan dan hukum kewarisan Islam ternyata sangat teramat adil dibanding ketentuan hukum kewarisan KUH Perdata, karena Hukum Islam tetap mendudukkan anak hasil zina sebagai orang yang terhormat, bermatabat, berharkat, dengan kedudukannya yang tetap mempunyai hubungan keperdataan dengan ibunya dan keluarga ibunya (Neng Djubaidah 2012: 85).

Selain itu, Hukum Islam yang melarang perzinaan oleh siapa pun juga, baik oleh orang-orang yang pernah atau masih terikat perkawinan, menunjukkan bahwa Hukum Islam sangat menjaga kemurnian hubungan darah secara sah, menjaga ketertiban masyarakat, melalui larangan perzinaan berdasarkan Surah An-Nisa Ayat 15 dan 16, Surah An-Nuur Ayat 2, Ayat 6 sampai dengan Ayat 9 
dan Ayat 13, larangan menuduh orang baik-baik melakukan zina tanpa menghadirkan empat orang saksi dalam surah An-Nuur Ayat 4 dan hadis Rasulullah di antaranya melalui ketentuan yang menentukan tidak terjadinya hubungan keperdataan antara anak hasil zina dengan ayah biologisnya dan keluarganya.

Menurut hukum Islam, meskipun ayah biologisnya menjadi suami ibunya, tetapi antara anak hasil zina dengan ayah biologisnya tersebut tetap tidak mempunyai hubungan hukum (nasab). Diantara mereka tidak dapat saling mewaris, tetapi hanya dapat saling memberi wasiat atau hibah (Neng Djubaidah 2012: 79).

Kompilasi Hukum Islam di Indonesia menyebutkan bahwa yang dimaksud dengan wasiat adalah pemberian suatu benda dari pewaris kepada orang lain atau lembaga yang akan berlaku setelah pewaris meninggal dunia (Pasal 171 huruf f). tententuan hukum wasiat ini terdapat dalam Pasal 194-209 yang mengatur secara keseluruhan prosedur tentang wasiat (Abdul Manan 2006: 150).

Para Ahli Hukum Islam mengatakan bahwa tidak ada ketunggalan hukum dalam soal nasab, sebab Hukum Islam sangat memerhatikan kemashalatan dan perlindungan terhadap anak yang lahir secara sah, demikian juga terhadap anak yang lahir di luar nikah atau zina patut diberi perlindungan sebab anak tersebut tidak berdosa, yang berdosa adalah kedua orang tuanya. Anak terlahir dalam keadaan suci dan tidak membawa dosa turunan, sekali pun ia terlahir sebagai hasil zina. Hal demikian ditetapkan oleh Fatwa Majelis Ulama Indonesia Nomor 11 Tahun 2012 tentang Kedudukan Anak Hasil Zina dan Perlakuan Terhadapnya. Oleh karena itu, anak hasil zina pun harus diperlakukan secara manusiawi, diberi pendidikan, pengajaran dan keterampilan yang berguna untuk bekal hidupnya dimasa depan. Tanggung jawab mengenai segala keperluan anak tersebut, baik materil maupun spiritual adalah ibunya yang melahirkannya dan keluarga ibunya.

Hukum menetapkan bahwa anak yang lahir dari suatu kehamilan karena hubungan seksual di luar perkawinan hanya memiliki hubungan dengan perempuan tersebut sebagai ibunya, adalah tidak tepat dan tidak adil pula jika hukum membebaskan laki-laki yang melakukan hubungan yang menyebabkan 
terjadinya kehamilan dan kelahiran anak tersebut dari tanggung jawabnya sebagai seorang bapak dan bersamaan dengan itu hukum meniadakan hak-hak anak terhadap lelaki tersebut sebagai bapaknya (Taufiqurrohman Syahuri 2013: 197).

Akibat hukum dari peristiwa hukum kelahiran karena kehamilan, yang didahului dengan hubungan seksual antara seorang perempuan dengan seorang laki-laki, adalah hubungan hukum yang di dalam nya terdapat hak dan kewajiban bertimbal balik, yang subjek hukumnya meliputi anak, ibu, dan bapak. Hubungan anak dengan seorang laki-laki sebagai bapak tidak semata-mata karena adanya ikatan perkawinan, tetapi dapat juga didasarkan adanya pembuktian adanya hubungan darah antara anak dengan laki-laki tersebut sebagai bapaknya (Taufiqurrohman Syahuri 2013: 198).

Anak yang dilahirkan harus mendapatkan perlindungan hukum, jika tidak demikian, maka yang dirugikan adalah anak yang dilahirkan di luar perkawinan atau zina, padahal anak tersebut tidak berdosa karena kelahirannya di luar kehendaknya. Anak yang lahir tanpa memiliki kejelasan status ayah sering kali mendapatkan perlakuan yang tidak adil dan stigma di tengah-tengah masyarakat, hukum harus memberikan perlindungan dan kepastian hukum yang adil terhadap anak yang dilahirkan dan hak-hak yang ada padanya (Taufiqurrohman Syahuri 2013: 198).

Anak hasil zina sedapat mungkin dilakukan perlindungan dan pencegahan terjadinya penelantaran, terutama dengan memberikan hukuman ta'zir kepada laki-laki yang menyebabkan kelahirannya untuk memenuhi kebutuhan hidupnya (memberikan biaya nafkah, pendidikan, kesehatan,dan lain-lain) sampai anak tersebut dewasa dan mandiri. Fatwa Majelis Ulama Indonesia Nomor 11 Tahun 2012 tentang Kedudukan Anak Hasil Zina dan Perlakuan Terhadapnya juga menegaskan diberikannya kemudahan kelayanan akte kepada anak hasil zina, tetapi tidak menasabkannya kepada lelaki yang mengakibatkan kelahirannya.

Pada dasarnya tidak ada manusia yang terlahir ke dunia ini dengan dosa dan secara biologis, tidak ada seorang pun anak terlahir tanpa memiliki orang tua, dalam hal ini ayah atau bapak. Mengenai beragamnya penyebutan terhadap status anak sendiri, seperti anak kandung, angkat, anak susu, anak tiri, dan anak di luar 
nikah (zina) hendaknya harus disikapi dengan bijak, agar tidak dapat menjadikan anak merasa terasingkan dan merasa terkucilkan, karena sesungguhnya anak yang dilahirkan dari seorang hamba-Nya (ibu) statusnya adalah suci. Sebagaimana dalam firman Allah SWT (QS. Maryam: 19)

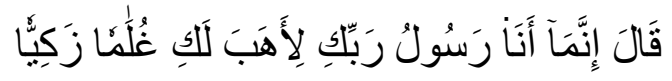

Artinya: Ia (jibril) berkata "sesungguhnya aku ini hanyalah seorang utusan

Tuhanmu, untuk memberimu seorang anak laki-laki yang suci”.

Selain itu dalam sabda Rasulullah SAW, dikatakan bahwa: "semua anak dilahirkan atas kesucian/kebersihan (dari segala dosa/noda) dan pembawaan beragama tauhid, sehingga ia jelas berbicaranya, maka kedua orang tuanyalah yang menyebabkan anaknya menjadi Yahudi atau Nasrani atau Majusi" (Hadits riwayat Abu Ya'la, At-Thabrani, dan Al-Baihaqi dari Al Aswad bin Sari).

\section{Simpulan dan Saran}

\section{Simpulan}

Berdasarkan uraian di atas, maka Kedudukan anak hasil zina adalah anak yang lahir di luar perkawinan, menurut Pasal 100 Kompilasi Hukum Islam hanya mempunyai hubungan nasab dengan ibunya dan keluarga ibunya sesuai Pasal 43 ayat (1). Apabila ketentuan hukum perkawinan dan hukum kewarisan KUH Perdata Barat yang berlaku di Indonesia saat ini dibandingkan dengan Hukum Islam berdasarkan Al-Qur'an dan Sunnah Rasulullah SAW maka hukum perkawinan dan hukum kewarisan Islam ternyata sangat teramat adil dibanding ketentuan hukum kewarisan KUH Perdata, karena Hukum Islam tetap mendudukkan anak hasil zina sebagai orang yang terhormat, bermatabat, berharkat dengan kedudukannya yang tetap mempunyai hubungan keperdataan dengan ibunya dan keluarga ibunya.

\section{Saran}

Anak hasil zina sedapat mungkin dilakukan perlidungan dan pencegahan terjadinya penelantaran, terutama dengan memberikan hukuman ta'zir kepada laki-laki yang menyebabkan kelahirannya untuk memenuhi kebutuhan hidupnya (memberikan biaya nafkah, pendidikan, kesehatan,dan lain-lain) sampai anak 
tersebut dewasa dan mandiri. Fatwa Majelis Ulama Indonesia Nomor 11 Tahun 2012 tentang Kedudukan Anak Hasil Zina dan Perlakuan Terhadapnya juga menegaskan diberikannya kemudahan kelayanan akte kepada anak hasil zina, tetapi tidak menasabkanya kepada lelaki yang mengakibatkan kelahirannya. 


\section{DAFTAR PUSTAKA}

\section{Buku:}

Abdul Manan. 2006. Aneka Masalah Hukum Perdata di Indonesia. Jakarta: Kencana Prenada Media Group.

Amiur Nuriddin dan Azhari Akmal Tarigan. 2004. Hukum Perdata di Indonesia (Studi Kritis Perkembangan Hukum Islam Dari Fikih, dan UU No.1/1974 sampai KHI. Jakarta: Kencana.

Andi Hamzah. 2007. Kitab Undang-undang Hukum Pidana. Jakarta: Rineka Cipta.

Munir Fuadi. 2014. Konsep Hukum Perdata. Jakarta: PT Raja GrafindoPersada.

Neng Djubaedah. 2010. Perzinaan, Dalam Peraturan Perundang-undangan di Indonesia Ditinjau dari Hukum Islam. Jakarta: Kencana.

---------. 2012. Pencatatan Perkawinan dan Perkawinan Tidak Dicatat Menurut Hukum Tertulis di Indonesia dan Hukum Islam, Jakarta: Sinar Grafika.

Subekti, R. dan R.Tjitrosudibio. 1999. Kitab Undang-undang Hukum Perdata. Jakarta: PT. Pradnya Paramita.

Taufiqurrohman Syahuri. 2013. Legislasi Hukum Perkawinan di Indonesia. Jakarta: Kencana.

\section{Peraturan Perundang-undangan:}

Republik Indonesia, Undang-Undang Nomor 1 Tahun 1974 tentang Perkawinan.

Republik Indonesia, Instruksi Presiden Nomor 1 Tahun 1991 tentang Kompilasi Hukum Islam. 


\section{BIODATA PENULIS}

$\begin{array}{ll}\text { Nama } & : \text { Lukman Hakim } \\ \text { Pekerjaan } & : \text { Fakultas Keguruan dan Ilmu Pendidikan Universitas } \\ & \text { Muhammadiyah Sumatera Utara } \\ \text { Jabatan } & : \text { Asisten Ahli } \\ \text { Nomor HP } & : \text { 081370505890 } \\ \text { E-mail } & : \text { lukman4dara@gmail.com @ gmail.com } \\ \text { Alamat Kantor } & : \text { Jl. Kapten Muchtar Basri No. 3, Medan }\end{array}$

